\title{
CCAAT enhancer binding protein $\beta$ promotes tumor growth and inhibits apoptosis in prostate cancer by methylating estrogen receptor $\beta$
}

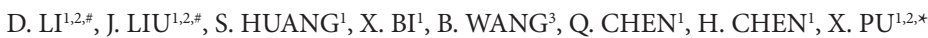 \\ ${ }^{1}$ Department of Urology, Guangdong General Hospital, Guangdong Academy of Medical Science, Guangzhou, Guangdong 510080, China; \\ ${ }^{2}$ Department of Urology, Guangdong General Hospital's Nanhai Hospital, The Second People's Hospital of Nanhai district, Foshan City, \\ Guangdong, 528251, China; ${ }^{3}$ Department of Urology, General Hospital of PLA, Beijing 100853, China
}

*Correspondence: xiaoyongpu0080@163.com

Received December 5, 2016 / Accepted May 2, 2017

\begin{abstract}
The CCAAT enhancer binding protein $\beta(\mathrm{C} / \mathrm{EBP} \beta)$ is overexpressed at late stages in carcinogenesis of prostate cancer $(\mathrm{PCa})$, suggesting that it could potentially contribute to progression of PCa. Estrogen receptor beta (ER $\beta$ ) is a tumor suppressor gene in $\mathrm{PCa}$. However, whether $\mathrm{C} / \mathrm{EBP} \beta$ could regulate $\mathrm{ER} \beta$ by promoter methylation is still poorly understood. In this study, expression levels of C/EBP $\beta$ and ER $\beta$ in two PC lines (LNCap and PC-3), prostatic epithelial cell line (RWPE-1), forty-eight paired non-cancerous and cancerous peripheral blood samples were examined via qRT-PCR, western blotting and methylation-specific PCR. In addition, PCa cell line was infected with pCDH-C/EBP $\beta$ and pLKO.1-C/ $\mathrm{EBP} \beta$ and expression levels of $\mathrm{C} / \mathrm{EBP} \beta, \mathrm{ER} \beta$ and DNA methyltransferases were detected. Finally, the role of $\mathrm{C} / \mathrm{EBP} \beta$ in proliferation and apoptosis of PCa cell lines was examined by MTT and flow cytometer assay. Our results show a higher frequency of promoter methylation of ER $\beta$ levels in blood samples from PCa patients ( 16 of 48 cases) compared with that from healthy controls ( 3 of 48). Besides, elevated expression levels of C/EBP $\beta$ were found in PCa patients and two PCa lines (LNCap and PC-3) compared to non-cancerous cases or prostatic epithelial cell line (RWPE-1), while opposite expression levels of $\mathrm{ER} \beta$ were found. Overexpression of C/EBP $\beta$ could regulate ER $\beta$ expression, DNA methyltransferases expression, cell proliferation and apoptosis. Our results support the conclusion that C/EBP $\beta$ down-regulated ER $\beta$ expression through increasing its promoter methylation, and then regulated proliferation and apoptosis in PCa.
\end{abstract}

Key words: $C / E B P \beta, E R \beta$, methylation, prostate cancer

Prostate cancer ( $\mathrm{PCa}$ ) is the most frequently diagnosed cancer in men which accounts for $44 \%$ of all cancer cases together with lung and bronchus, and colorectal cancers cases. Among these three kinds of cancer, PCa alone accounts for 1 in 5 new diagnoses. In 2016, it is estimated that over 180,890 patients were diagnosed with PCa and 26,120 of them will succumb to death in USA [1]. As is known to all, carcinogenesis is the result of an interaction between genetic and environmental factors, which varies between ethnic backgrounds, individuals and sexes [2]. More and more evidence in the past decades suggests that epigenetic alterations play an important role in the generation and progression of PCa by silencing tumor suppressor genes [3-5]. The most common mode of epigenetic variation which may lead to tumorigenesis is methylation in $\mathrm{CpG}$ islands in the promoter of tumor suppressor genes [6]. However, the current information of PCa that involves a clear epigenetic component remains incompletely understood and its application in clinical practice is also limited [7].

CCAAT enhancer binding protein $\beta(\mathrm{C} / \mathrm{EBP} \beta)$, a member of transcription factor family $(\mathrm{C} / \mathrm{EBP} \alpha, \beta, \gamma, \delta, \varepsilon$ and $\zeta)$, contains a basic leucine-zipper domain for DNA binding and dimerization [8]. $\mathrm{C} / \mathrm{EBP} \beta$ is reported to have opposing functions in several different cell types. It can terminate cell differentiation and growth arrest and can also promote proliferation in other cell types [9]. C/EBP $\beta$ is overexpressed in late stages of PCa [10] and has also been suggested to be a co-repressor of androgen receptor in $\mathrm{PCa}$, and to participate in regulation of $\mathrm{PCa}$ cell proliferation and $\mathrm{PCa}$ metastasis [10-13]. Although previous studies indicate that $\mathrm{C} / \mathrm{EBP} \beta$ affects PCa through regulating the expression of several DNA damage response- and invasion-related genes, the concrete underlying mechanism and related signaling pathways have not been clearly identified yet. 
Estrogen receptors (ER) represent a family of receptors that are activated by hormone estrogen with two classes: ERa and ER $\beta$ [14]. ER $\beta$, predominantly expressed in the epithelium of prostate, was reported to inhibit promote differentiation, cell proliferation and induce apoptosis excessively [15, 16]. Recent studies found that the ER $\beta$ expression in PCa tissues was decreased, indicating that the ER $\beta$ might be a tumor suppressor gene in prostate cancer $[17,18]$. Lots of researches have reported that the promoter hypermethylation of $\mathrm{CpG}$ islands was associated with down-expression of some tumor suppressors in cancer $[19,20]$. In the present study, we hypothesized that overexpression of $\mathrm{C} / \mathrm{EBP} \beta$ may result in ER $\beta$ promoter methylation, and then lead to the etiological mechanisms of PCa. The expression of $\mathrm{C} / \mathrm{EBP} \beta$ and the methylation status of the ER $\beta$ promoter were examined using genomic DNA extracted from peripheral blood of $\mathrm{PCa}$ patients and corresponding healthy controls. Our hypothesis was further supported experimentally by using prostatic epithelial and cancer cell lines.

\section{Patients and methods}

Subject and sample collection. Peripheral blood samples from $48 \mathrm{PCa}$ patients were obtained from the collections at the department of urology, Guangdong general hospital. They were clinically diagnosed with PCa from January 2015 to July 2016 and their baseline clinical data are shown in Table 1. Meanwhile, 48 peripheral blood samples were randomly collected from healthy controls during a routine physical examination. Healthy controls subjects had no known history of hormone-sensitive diseases. All patients provided written informed consent for their blood samples to be utilized in this research. This study was approved by the ethics committee of Guangdong general hospital.

Quantitative real-time PCR analysis. RNA was extracted from all peripheral blood samples using an RNAprep Pure Hi-Blood Kit according to the manufacturer's protocol (Tiangen Biotech Co., Ltd., Beijing, China). OD260/280 was determined to assess the purity of RNA. The Easyscript First-Strand cDNA Synthesis SuperMix kit (TransGen, Co., Ltd., Beijing, China) was used for reverse transcription PCR. Primers for $C / E B P \beta$ and ER $\beta$ (Table 2) were dissolved in RNase-free water to the recommended concentrations according to primer data sheets. Quantitative PCR reactions were conducted as previously described.

Western blotting. Total proteins from the peripheral blood samples were extracted, and cells were collected in $1.5 \mathrm{ml}$ tubes and washed twice with PBS, and then placed on ice for $30 \mathrm{~min}$ in RIPA lysis buffer (Beyotime Institute of Biotechnology, Shanghai, China) with $1 \mathrm{mM}$ PMSF (Shanghai Sangon Biotech Co., Ltd, Shanghai, China). Supernatants were acquired by centrifugation at $13,000 \mathrm{rpm}$ for $15 \mathrm{~min}$ at $4^{\circ} \mathrm{C}$. Subsequently, protein concentration was detected by the BCA Protein Quantitative Assay (Shanghai Sangon Biotech Co., Ltd, Shanghai, China). Total $40 \mu \mathrm{g}$ protein sample was separated on $12 \%$ SDS-PAGE gel, and then transferred onto PVDF membranes, which were blocked in 5\% nonfat milk for $1 \mathrm{~h}$. The membranes were incubated overnight at $4{ }^{\circ} \mathrm{C}$ with mouse anti-human $\beta$-actin monoclonal antibody (1:1000, Santa Cruz, CA, USA), mouse polyclonal antibody against ER $\beta$ (1:1000, Abcam, CA, USA) and mouse polyclonal antibody against $\mathrm{C} / \mathrm{EBP} \beta(1: 1000, \mathrm{Abcam}, \mathrm{CA}, \mathrm{USA})$ and were washed for three times with PBS, then incubated with goat anti-mouse $\operatorname{IgG}(\mathrm{H}+\mathrm{L})$-HRP (1:5000, Jackson immunoResearch, PA, USA) or goat anti-rabbit IgG(H+L)-HRP (1:5000, Jackson immunoResearch, PA, USA) for $2 \mathrm{~h}$ at room temperature, respectively. Ultimately, the proteins were detected with Enhanced chemiluminescence (ECL, Millipore, MA, USA) and analyzed with the densitometry software Image J.

Methylation-specific PCR (MS-PCR) and sequencing analysis. The methylation status of ER $\beta$ was measured by MS-PCR which can distinguish between un-methylated DNA and methylated DNA. Genomic DNA was extracted from all peripheral blood samples using a TIANamp Blood DNA Kit according to the manufacturer's protocol (Tiangen BIOTECH Co., Ltd., Beijing, China). Extracted genomic DNA was treated with bisulfite using CpGenome TM DNA Modification Kit (CHEMICON International, Temecula, CA, USA) according to the manufacturer's instruction. PCR amplification was carried out as previously described [21]. The PCR products were separated on a $2 \%$ agarose gel, then extracted from the gel and purified.

Cell culture. The human prostate cancer cell lines (PC-3 and $\mathrm{LNCaP}$ ) and prostatic epithelial cell line (RWPE-1) were

Table 1. Frequency distributions of clinical data in prostate cancer cases and healthy controls.

\begin{tabular}{lcc}
\hline Variables & Prostate cancer cases & Healthy controls \\
\hline Number & 48 & 48 \\
Age at sample collection & 2 & 4 \\
$50-59$ & 20 & 22 \\
$60-69$ & 22 & 18 \\
$70-79$ & 4 & 4 \\
$\geq 80$ & & - \\
Gleason scores & 18 & \\
$6-7$ & 22 & \\
$8-9$ & 3 & - \\
10 & 5 & \\
Unclear & & \\
Serum PSA & 2 & - \\
$<4$ & 9 & \\
$4-10$ & 37 & \\
$>10$ & & \\
Bone metastasis & 10 & \\
Yes & 38 & \\
No & & \\
Surgery & 12 & \\
Yes & 36 & \\
No & & \\
\hline & & \\
& &
\end{tabular}


Table 2. Primer sequences used for PCR in methylation status analysis and quantitative real-time PCR in ER $\beta$ mRNA expression.

\begin{tabular}{lll}
\hline Target & $\begin{array}{l}\text { Primer sequence }\left(\mathbf{5}^{\prime} \rightarrow \mathbf{3}^{\prime}\right) \\
\text { Forward }\end{array}$ & $\begin{array}{l}\text { Size } \\
(\mathbf{b p})\end{array}$ \\
\hline MSP-M & ATTGTTTTTTGAAATTTGTAGGGC & ACCTTCTCTAAAATACGAACACGTA \\
MSP-U & GTTTTTTGAAATTTGTAGGGTGA & ACCTTCTCTAAAATACAAACACATA \\
BSP & TAGTAGATGTGGAATTGGAGAGTTTG & AATAACCCCAACACAAAAAAAAC \\
ER $\beta$ & TTCCCTCCACCTTCCCAAC & GGTTAGCCCACTTCTGTAAGCG \\
GAPDH & CGGAGTCAACGGATTTGGTCGTAT & AGCCTTCTCCATGGTGGTGAAGAC \\
\hline
\end{tabular}

Table 3. Primer sequences used for quantitative real-time PCR in DNA methyltransferases.

\begin{tabular}{lll}
\hline Gene & Forward primer & Reverse primer \\
\hline DNMT1 & CGACTACATCAAAGGCAGCAACCTG & TGGAGTGGACTTGTGGGTGTTCTC \\
DNMT2 & AAGCTGTAAGCCAGCCCATATAC & TCAGCAGTGAACAGAACCTACATG \\
DNMT3A & CGAGTCCAACCCTGTGATGATTG & GCTGGTCTTTGCCCTGCTTTATG \\
DNMT3B & TTGGAATAGGGGACCTCGTGTG & AGAGACCTCGGAGAACTTGCCATC \\
\hline
\end{tabular}

obtained from American Type Culture Collection (ATCC). PC-3 and LNCaP were cultured in Dulbecco's Modified Eagle Medium (DMEM, Gibco, Carlsbad, CA, USA) supplemented with $10 \%$ fetal bovine serum (FBS) and RWPE-1 was cultured in Keratinocyte-SFM Serum Free Medium (Invitrogen, Life Technology Co., Ltd., CA, USA) in an atmosphere of $95 \%$ air and $5 \% \mathrm{CO} 2$ at $37^{\circ} \mathrm{C}$.

Construction of lentivirus vector. Human C/EBP $\beta$ gene was synthesized by Shanghai Sangon Biotech Co., Ltd (Shanghai, China) and was cloned into $\mathrm{pCDH}$ lentiviral vector. In $\mathrm{pCDH}$ lentiviral vector, the green fluorescent protein (GFP) was a single transcript under the control of a CMV promoter and expressed after the transcription of C/EBP $\beta$ gene. To knockdown C/EBP $\beta$ expression, the interfering sequence 5'-CCT TTA GAC CCA TGG AAG TTT-3' was selected. The oligonucleotides were annealed and the double-stranded oligonucleotides were cloned into $\mathrm{pLKO} .1$ vector. The lentiviral vector $\mathrm{pCDH}, \mathrm{pCDH}-\mathrm{C} / \mathrm{EBP} \beta$, pLKO.1- shNC (negative control) and pLKO.1-shC/EBP $\beta$ were co-transfected with the corresponding helper plasmids into 293T cells by Lipofectamine 2000 (Invitrogen, Carlsbad, CA, USA), respectively. After 6 h, DMEM was exchanged by complete medium (containing 10\% FBS). The supernatant was harvested after culturing for $48 \mathrm{~h}$ and concentrated by ultrafiltration. PCa cell lines were infected with recombinant lentivirus $\mathrm{pCDH}, \mathrm{pCDH}-\mathrm{C} / \mathrm{EBP} \beta$, pLKO.1- shNC and $\mathrm{pLKO} .1-\mathrm{shC} / \mathrm{EBP} \beta$, respectively. Cells without infection served as blank group. Medium was replaced by fresh medium $24 \mathrm{~h}$ post-infection, and cells were collected $72 \mathrm{~h}$ post-infection for subsequent analysis.

Quantitative real-time PCR analysis of DNA methyltransferases. The relative expression levels of DNA methyltransferases including DNMT1, DNMT2, DNMT3A and DNMT3B were determined in all five groups as described above. The primers were provided in Table 3.

Methyl thiazolyl tetrazolium (MTT) assay. The $1 \times 10^{4}$ cells were seeded into each well of a 96-well plate. On the second day, the cells were infected with lentivirus $\mathrm{pCDH}$, pCDH-C/EBP $\beta$, pLKO.1- shNC and pLKO.1-sh C/EBP $\beta$, respectively, and then the cells were incubated for various periods of time $\left(37^{\circ} \mathrm{C}, 5 \% \mathrm{CO}_{2}\right.$ and saturation humidity). MTT $(10 \mu \mathrm{l}, 5 \mathrm{mg} / \mathrm{mL})$ (Shanghai Sangon Biotech Co., Ltd, Shanghai, China) was added into each well at the same time every day and then the cells were incubated for $4 \mathrm{~h}$. Dimethyl sulfoxide (DMSO, $100 \mu$ l, Shanghai Sangon Biotech Co., Ltd, Shanghai, China) was later added into each well to solubilize the formazan crystals. The zero hole (medium, MTT, DMSO) and blank hole were set up. The absorbance was read at $570 \mathrm{~nm}$ using a microplate reader (Molecular Devices, CA, USA). All determinations were carried out in triplicate.

Flow cytometer assay. For cell cycle detection, the cells with infection were digested with $0.25 \%$ Trypsin (Invitrogen, Carlsbad, CA, USA) and collected by centrifugation at 1,500 rpm for $6 \mathrm{~min}$, then washed with phosphate buffer saline (PBS, Shanghai Sangon Biotech Co., Ltd, Shanghai China) once. Cells were fixed with ice-cold $75 \%$ ethanol at $4^{\circ} \mathrm{C}$ overnight and then centrifuged $(1,500 \mathrm{rpm}$ for $6 \mathrm{~min}$ ) and ethanol was removed by washing with PBS. Cells were slightly resuspended with $300 \mu \mathrm{PBS}$ and treated with $50 \mu \mathrm{g} / \mathrm{ml}$ RNase A (Shanghai Sangon Biotech Co., Ltd, Shanghai, China) for $30 \mathrm{~min}$ at $37^{\circ} \mathrm{C}$. The cells were stained with propidium iodide (PI, BioLegend, USA) in the dark for $15 \mathrm{~min}$ at $4{ }^{\circ} \mathrm{C}$ and detected by flow cytometer (BD, San Diego, CA, USA). Annexin V-APC Apoptosis Detection kit (BD, San Diego, CA, USA) was used to detect the cell apoptosis.

Statistical analysis. All statistical analyses were performed using SPSS version 17.0 (SPSS Inc., Chicago, IL, USA). Data were presented as mean \pm standard deviation (SD). One-way analysis of variance (ANOVA) was used to analyze the difference between groups, followed by student's $t$ test. Statistical analyses of methylated cases were conducted using Chi square test to compare the two sets of enumeration data. A $p<0.05$ was regarded as statistically significant. 
Table 4. Comparison of methylation status of the promoter in ER $\beta$ between prostate cancer patients and healthy controls.

\begin{tabular}{|c|c|c|c|c|}
\hline \multirow[b]{2}{*}{ Methylation status } & \multicolumn{2}{|c|}{ Numbers (\%) } & \multirow[b]{2}{*}{ p-value ${ }^{a}$} & \multirow[b]{2}{*}{ OR $(95 \% \mathrm{CI})^{\mathrm{b}}$} \\
\hline & $\begin{array}{c}\text { Prostate cancer } \\
(n=48)\end{array}$ & $\begin{array}{l}\text { Healthy controls } \\
(n=48)\end{array}$ & & \\
\hline Unmethylated & $32(66.67 \%)$ & $45(93.75 \%)$ & & \\
\hline methylated & $16(33.33 \%)$ & $3(6.25 \%)$ & 0.046 & $3.000(0.983-9.158)$ \\
\hline
\end{tabular}

${ }^{a} \mathrm{p}$-values were analyzed for the frequencies of methylation status between prostate cancer cases and healthy controls, $\mathrm{p}$-values were determined by the $\mathrm{x}^{2}$ test 'OR $(95 \% \mathrm{CI})$ were calculated as the unmethylated as reference

\section{Results}

Methylation analysis of the ER $\beta$ promoter in PCa. MS-PCR analysis was performed to identify the methylation status of 48 PCa cases and 48 healthy controls. Sample S3 and S15 in PCa group displayed a clear methylated band which represented methylated DNA (Figure 1). However, S1 and S2 in control group showed no methylated bands. Total 16 cases in 48 prostate cancer patients (33.33\%) showed positive methylation in the ER $\beta$ promoter while 3 cases in 48 healthy controls $(6.25 \%)$ were determined as methylation-positive. The methylation frequency in the ER $\beta$ promoter was significantly higher in PCa patients than that in healthy controls $(\mathrm{p}<0.05$, Table 4$)$.

Expression of C/EBP $\boldsymbol{\beta}$ and ER $\boldsymbol{\beta}$ in PCa. The expression levels of $\mathrm{C} / \mathrm{EBP} \beta$ and $\mathrm{ER} \beta$ gene were determined in PCa patients and healthy controls and in three cell lines on both mRNA and protein levels. In Figure 2, we can see that the expression of ER $\beta$ in blood samples from PCa patients was significantly lower than that from healthy controls $(\mathrm{p}<0.05)$, while the expression of $\mathrm{C} / \mathrm{EBP} \beta$ in blood samples from $\mathrm{PCa}$ patients was significantly higher than that from healthy

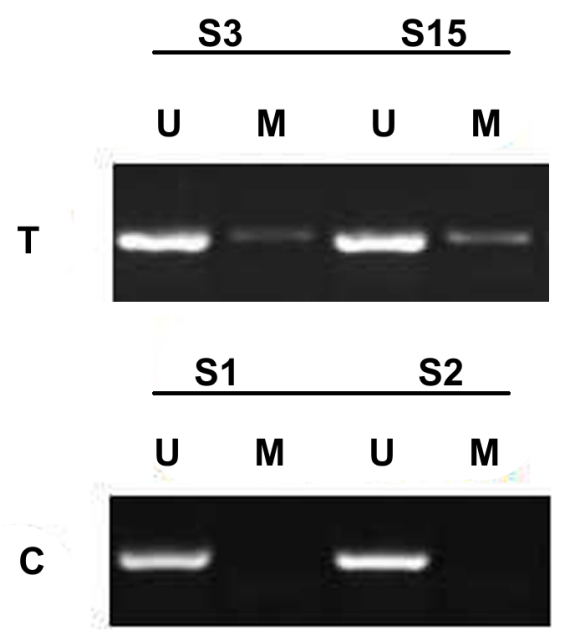

Figure 1. Methylation status of the promoter of the estrogen receptor (ER) $\beta$ gene in genomic DNA from prostate cancer patients (T) and healthy controls $(C)$. M methylated band, $U$ unmethylated band. Numbers indicate the sample number. controls $(\mathrm{p}<0.05)$. Same expression modes of these two genes were detected in PCa lines and non-cancerous cells on both mRNA and protein levels.

Expression of $\mathrm{C} / \mathrm{EBP} \boldsymbol{\beta}$ and $\mathrm{ER} \boldsymbol{\beta}$ in lentiviral vectors. The stable overexpression or downexpression of $\mathrm{C} / \mathrm{EBP} \beta$ was examined by western blot. Recombinant lentiviruses pCDH, pCDH-C/EBP $\beta$, pLKO.1-shNC and pLKO.1-shC/ $\mathrm{EBP} \beta$ were efficiently transfected into LNCaP cells and PC-3 cells (Figure 3A-D). Additionally, western blotting analysis suggested that the expression of $\mathrm{C} / \mathrm{EBP} \beta$ was remarkably increased in $\mathrm{pCDH}-\mathrm{C} / \mathrm{EBP} \beta$ group compared to that in the pCDH and blank groups in both LNCaP cells and PC-3 cells, while that in $\mathrm{pLKO} .1-\mathrm{shC/EBP} \beta$ was significantly reduced. These results demonstrate that lentiviral vector $\mathrm{pCDH}-\mathrm{C} /$ $\mathrm{EBP} \beta$ and $\mathrm{pLKO} .1-\mathrm{shC} / \mathrm{EBP} \beta$ were successfully constructed and lentivirus had a high efficiency of infection.

Furthermore, the expression of ER $\beta$ was determined by western blot analysis in order to investigate effect of C/EBP $\beta$ overexpression and downexpression. The expression level of $\mathrm{ER} \beta$ in $\mathrm{pCDH}-\mathrm{C} / \mathrm{EBP} \beta$ was significantly reduced compared with that in empty vector group and blank group, while in pLKO.1-shC/EBP $\beta$ it was significantly increased in both LNCaP and PC-3 cells (Figure 3A, C, and E).

Expression of DNA methyltransferases. We further examined whether the expression levels of DNA methyltransferases genes were affected in overexpression or downexpression of $\mathrm{C} / \mathrm{EBP} \beta$ cells. By a quantitative real-time PCR method, transcripts from all DNMTs were detected in blank, pCDH, pCDH-C/EBP $\beta$, pLKO.1- shNC and pLKO.1shC/EBP $\beta$ groups. However, DNMT1 and DNMT3B were expressed at higher levels in $\mathrm{pCDH}-\mathrm{C} / \mathrm{EBP} \beta$ cells than those in the blank and pCDH cells, while in pLKO.1-shC/EBP $\beta$ cells they were expressed at lower levels $(\mathrm{p}<0.05)$. The other two genes (DNMT2 and DNMT3A) were expressed in same trends but without significance (Table 5 ). This result suggests that overexpression of $\mathrm{C} / \mathrm{EBP} \beta$ might have some relevance to methylation status.

Effect of C/EBP $\beta$ on cell proliferation and apoptosis of LNCaP cell. To explore the effects of C/EBP $\beta$ overexpression on PCa cell proliferation, MTT analysis was performed in our study. The results show that the absorbance of LNCaP cells and PC-3 cells was significantly increased in $\mathrm{pCDH}-\mathrm{C} /$ $\mathrm{EBP} \beta$ group at $72 \mathrm{~h}$ compared with that in blank and empty vector groups, while in $\mathrm{pLKO} .1-\mathrm{shC} / \mathrm{EBP} \beta$ group it was significantly decreased (Figure 4 ). The apoptotic rate in 
A

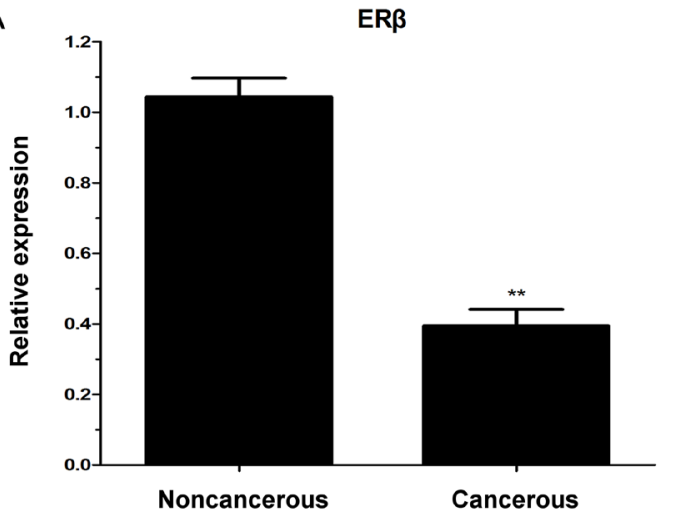

C

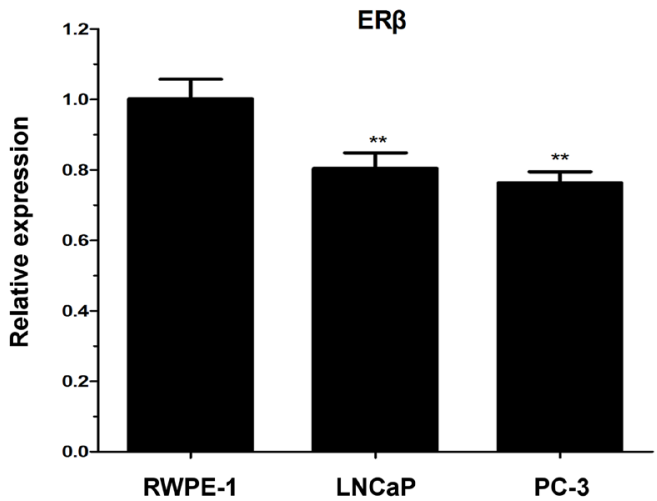

B

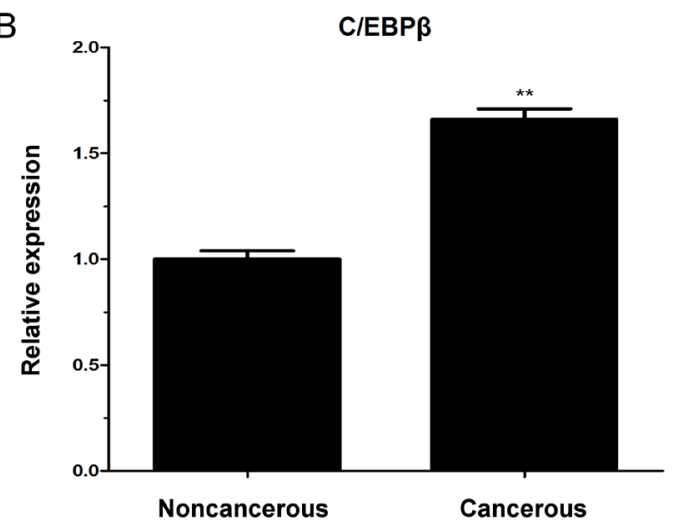

D

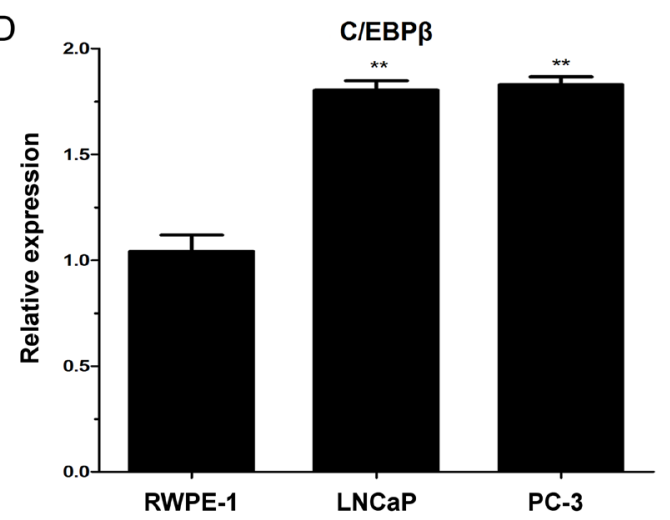

$\mathrm{E}$

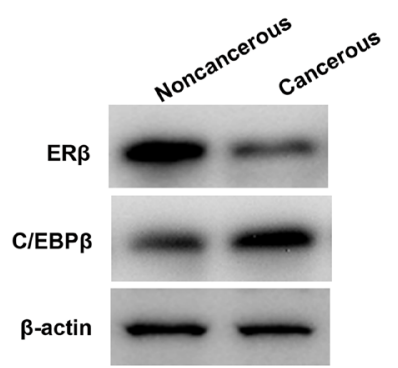

$\mathrm{H}$

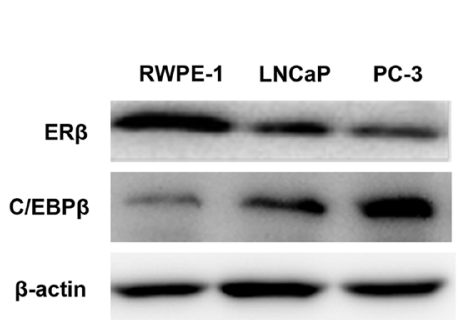

$\mathrm{F}$

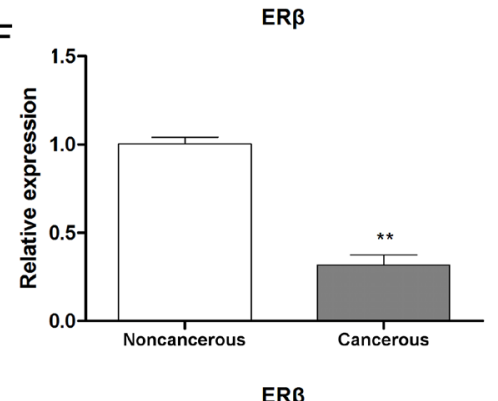

ERB

G
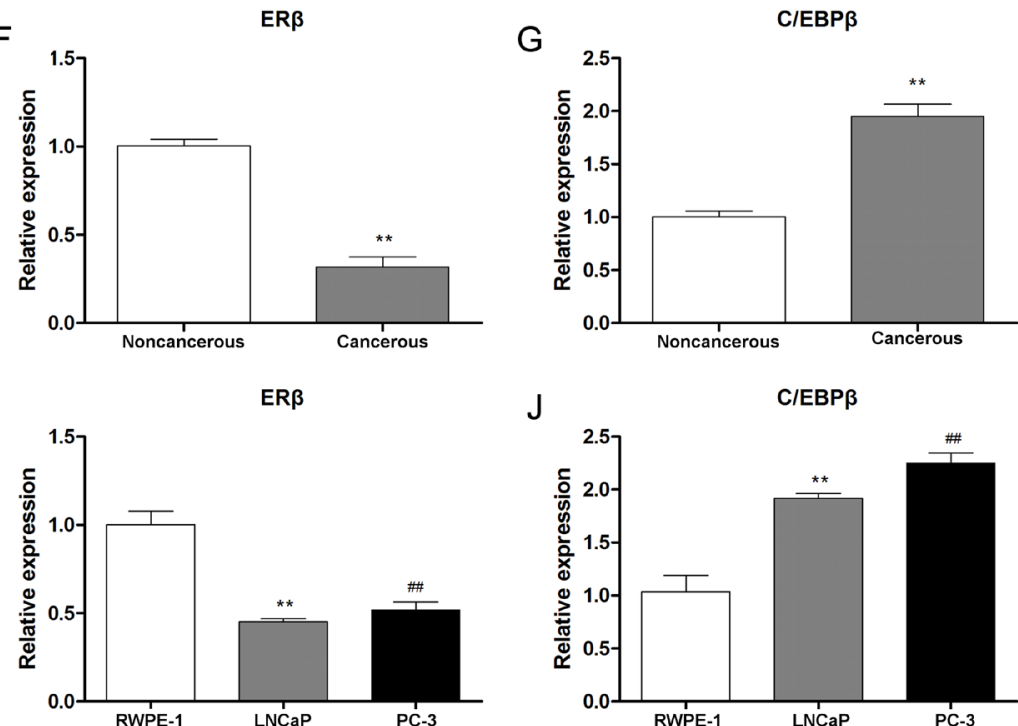

$J$

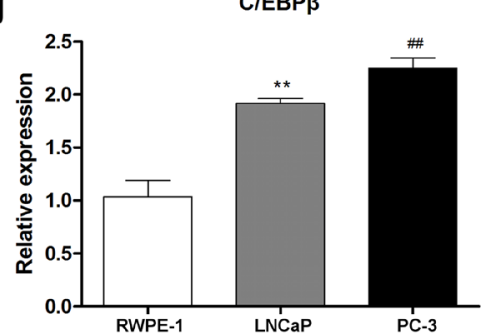

Figure 2. The expression of the C/EBP $\beta$ and ER $\beta$ gene at the transcription level in non-cancerous, cancerous blood samples and cells (A-D). The expression of the C/EBP $\beta$ and ER $\beta$ gene at the translation level in prostate cancer $(\mathrm{E}-\mathrm{G})$ and prostatic epithelial cell lines $(\mathrm{H}-\mathrm{J})$. Data were shown as mean \pm SD. ${ }^{* *} \mathrm{p}<0.01$ versus control.

LNCaP cells was quantitatively analyzed by flow cytometry and the results show that apoptotic cells ratio was diminished in $\mathrm{pCDH}-\mathrm{C} / \mathrm{EBP} \beta$ group compared to that in $\mathrm{pCDH}$ group $(\mathrm{p}<0.05$, Table 6). Besides, the apoptotic rate in $\mathrm{pLKO} .1-\mathrm{C} /$
$\mathrm{EBP} \beta$ group was significantly increased compared to that in pLKO.1-NC group $(\mathrm{p}<0.05)$. These data suggested that $\mathrm{C} /$ EBP $\beta$ plays a vital role in maintaining cell proliferation and apoptosis. 
A

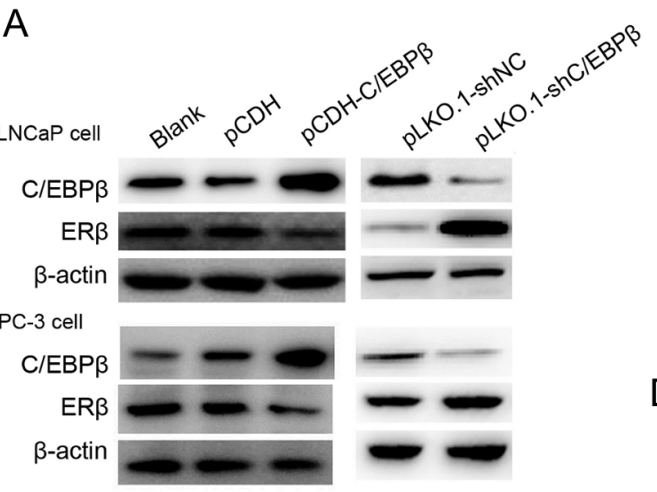

B

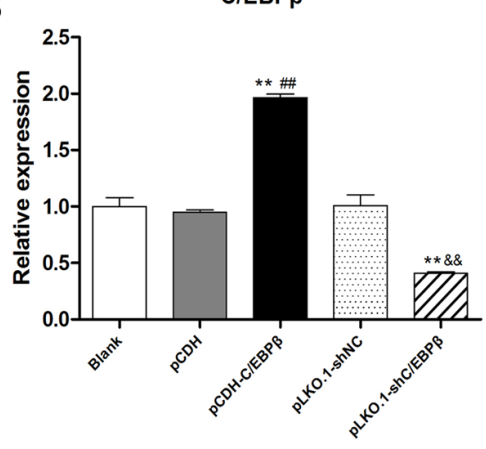

D

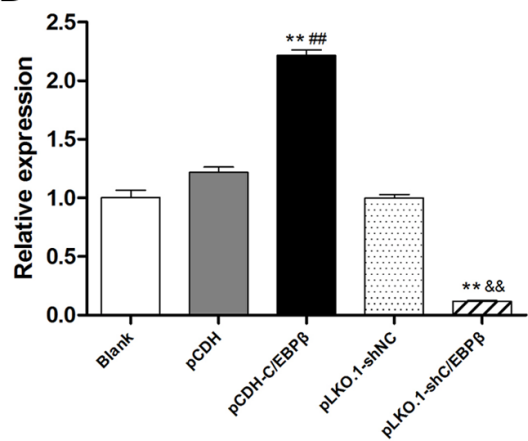

C

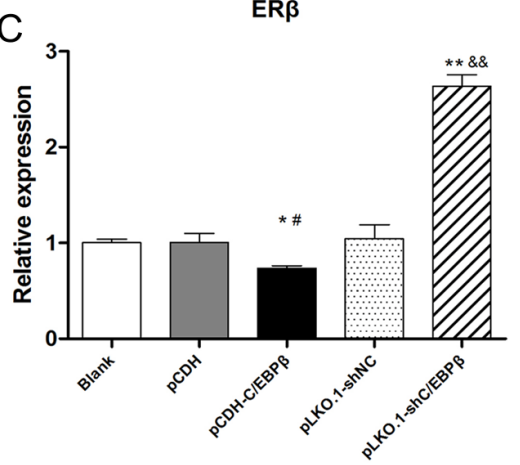

E

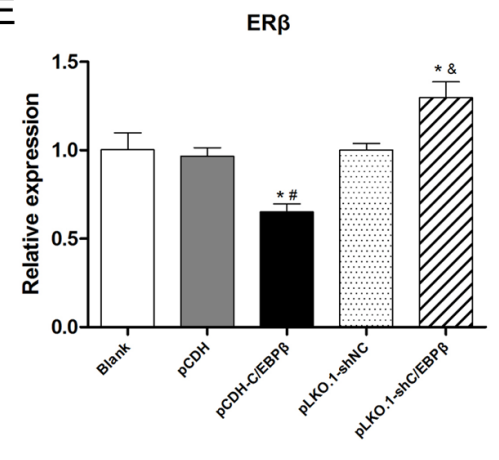

Figure 3. Lentiviral vectors $\mathrm{pCDH}-\mathrm{C} / \mathrm{EBP} \beta$ and $\mathrm{pLKO}$.1-C/EBP $\beta$ were successfully constructed and had a high efficiency of infection in both LNCaP cells and PC-3 cells; expression of ER $\beta$ in LNCaP and PC- 3 cell line was measured by western blotting and the representative gel electrophoresis bands were shown (A). Quantitative analysis of $\mathrm{C} / \mathrm{EBP} \beta$ and ER $\beta$ expression levels in LNCaP cells (B-C) and PC-3 cells (D-E). Data were shown as mean \pm SD. ${ }^{* *} \mathrm{p}<0.01$ versus blank; ${ }^{\# \#} \mathrm{p}<0.01$ versus $\mathrm{pCDH} ;{ }^{8 *} \mathrm{p}<0.01$ versus $\mathrm{pLKO} .1-\mathrm{C} / \mathrm{EBP} \beta$.

Table 5. The expression levels of DNA methyltransferases.

\begin{tabular}{lllll}
\hline & DNMT1 & DNMT2 & DNMT3A & DNMT3B \\
\hline Blank & $1.06 \pm 0.25$ & $1.03 \pm 0.14$ & $1.04 \pm 0.21$ & $1.02 \pm 0.11$ \\
pCDH & $0.98 \pm 0.19$ & $1.09 \pm 0.23$ & $0.97 \pm 0.14$ & $0.96 \pm 0.22$ \\
pCDH-C/EBP $\beta$ & $1.38 \pm 0.24^{* *}$ & $1.17 \pm 0.14$ & $1.08 \pm 0.20$ & $1.30 \pm 0.18^{* *}$ \\
pLKO.1-shNC & $0.98 \pm 0.21$ & $0.99 \pm 0.24$ & $1.03 \pm 0.16$ & $1.07 \pm 0.26$ \\
pLKO.1-shC/EBP $\beta$ & $0.78 \pm 0.18^{* \&}$ & $0.93 \pm 0.13$ & $0.89 \pm 0.19$ & $0.82 \pm 0.12^{* \&}$ \\
\hline
\end{tabular}

${ }^{*} \mathrm{p}<0.05$ versus Blank, ${ }^{*} \mathrm{p}<0.05$ versus $\mathrm{pCDH},{ }^{8} \mathrm{p}<0.05$ compared with pLKO.1-shNC.

Table 6. Cell apoptosis in three groups.

\begin{tabular}{lc}
\hline Group & Apoptotic cells ratio (\%) \\
\hline Blank & $12.14 \pm 0.89$ \\
pCDH & $20.32 \pm 1.86^{*}$ \\
pCDH-C/EBP $\beta$ & $15.49 \pm 0.51^{* \sharp}$ \\
pLKO.1-shNC & $19.09 \pm 1.17^{*}$ \\
pLKO.1-shC/EBP $\beta$ & $26.06 \pm 1.43^{* *}$ \\
\hline
\end{tabular}

${ }^{*} \mathrm{p}<0.05$ versus Blank, ${ }^{*} \mathrm{p}<0.05$ versus $\mathrm{pCDH},{ }^{8} \mathrm{p}<0.05$ compared with pLKO.1-shNC.
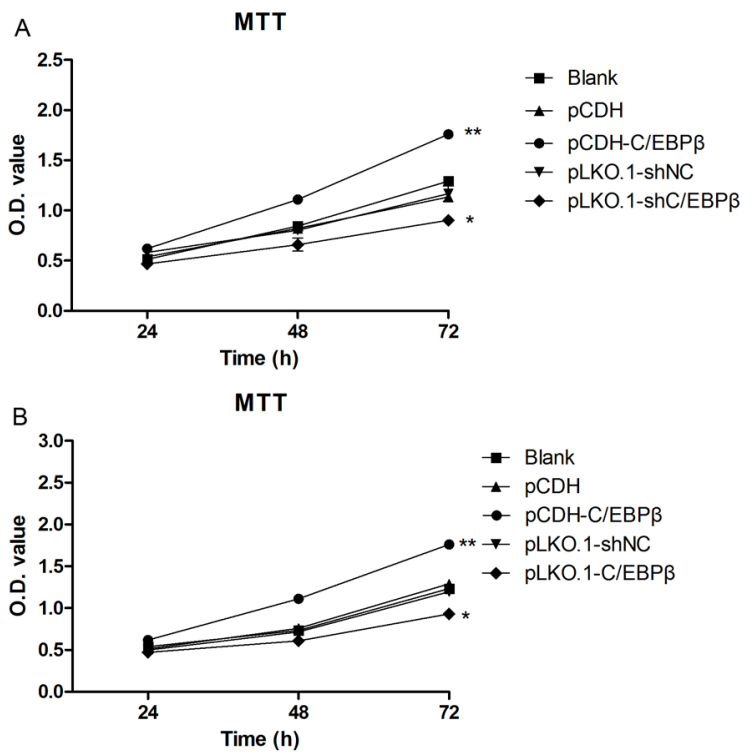

Figure 4. C/EBP $\beta$ regulated $\mathrm{LNCaP}$ cell proliferation in $\mathrm{LNCaP}$ cells (A) and PC-3 cells $(\mathrm{B}) .{ }^{* *} \mathrm{p}<0.01$ versus control; ${ }^{*} \mathrm{p}<0.05$ versus control. 


\section{Discussion}

PCa is the most frequently diagnosed cancer in men. However, the prognosis including low cure rate and easy recurrence of $\mathrm{PCa}$ is poor because of lack of effective therapies. Therefore, there is an urgent need to investigate the molecular mechanisms of $\mathrm{PCa}$ in order to screen more therapy targets. In this study, we found that the methylation frequency of ER $\beta$ was significantly higher in PCa patients than in healthy controls. Further in vitro analysis demonstrated that overexpression of C/EBP $\beta$ in PCa could downregulate the expression of ER $\beta$ and further lead to increase of PCa cell proliferation and decrease of cell apoptosis. These results indicate that $\mathrm{C} / \mathrm{EBP} \beta$ plays a central role in $\mathrm{PCa}$ tumorgenesis, and suggest the $\mathrm{C} / \mathrm{EBP} \beta$ as a potential therapeutic target in PCa.

$\mathrm{ER} \beta$ is a tumor suppressor gene which was reported to induce cell apoptosis, inhibit cell proliferation and promote cell differentiation. In this study, the methylation status of ER $\beta$ was detected in PCa patients by MS-PCR. Among the $48 \mathrm{PCa}$ patients, in 16 of them (33.33\%) hypermethylation in promoter of ER $\beta$ was found, while only $6.25 \%$ of healthy controls were found methylated in ER $\beta$. Previous studies have demonstrated that high methylation of tumor suppressor gene could lead to decreased expression of these suppressor genes in tumor tissue [22]. Therefore, we hypothesized that $\operatorname{ER} \beta$ promoter methylation may result from overexpression of $\mathrm{C} / \mathrm{EBP} \beta$ in PCa patients. Furthermore, we observed increase in the expression of DNA methyltransferases including DNMT1, DNMT3B $(\mathrm{p}<0.05)$, DNMT2 and DNMT3A $(\mathrm{p}>0.05)$ at a transcript level in $\mathrm{pCDH}-\mathrm{C} / \mathrm{EBP} \beta$ group. These de novo DNA methyltransferase enzymes are responsible for DNA methylation [23]. The upregulation of DNA methyltransferases in our study further confirmed the association between C/EBP $\beta$ and DNA methylation status.

In some normal cells, C/EBP $\beta$ has been shown to have anti-proliferative effects. As previously described, C/EBP $\beta$ can interact with the retinoblastoma protein family to suppress the expression of E2F target genes (S-phase genes), then inhibit the cell proliferation in human primary fibroblasts [9]. Reducing C/EBP $\beta$ expression could resist the calcium induced growth arrest in primary keratinocytes [24]. However, C/EBP $\beta$ displays promoting effects on cell proliferation in tumor cells. Inhibition of C/EBP $\beta$ expression significantly inhibited glioblastoma cells proliferation and invasion, and also prolonged survival in a murine brain tumor model [25]. In PCa, Barakat et al. found that C/EBP $\beta$ expression is negatively regulated by androgen receptor activity and expression levels of $\mathrm{C} / \mathrm{EBP} \beta$ are significantly elevated in Castration-resistant PCa samples compared to those in benign prostate. Our study was consistent with their findings in the elevated expression of C/EBP $\beta$ in PCa samples.

To further validate our hypothesis, we constructed an overexpression lentiviral vector $\mathrm{pCDH}-\mathrm{C} / \mathrm{EBP} \beta$ and downexpression lentiviral vector $\mathrm{pLKO} .1-\mathrm{C} / \mathrm{EBP} \beta$ and trans- fected these lentiviral vector into PCa cells. Our in vitro experiments suggest that expression level of ER $\beta$ was significantly reduced in $\mathrm{pCDH}-\mathrm{C} / \mathrm{EBP} \beta$ cells and was remarkably increased in $\mathrm{pLKO} .1-\mathrm{C} / \mathrm{EBP} \beta$ cells, suggesting the interaction between $\mathrm{C} / \mathrm{EBP} \beta$ and $\mathrm{ER} \beta$.

There were inevitably certain limitations in the current study. First of all, we analyzed the methylation status using a qualitative approach. More quantitative methylation measurements such as pyrosequencing and quantitative-MSP will be adopted in our further studies which may provide more analytical power to the investigation. Moreover, these observations need to be vigorously examined in our future research. It would also be meaningful to follow those healthy subjects who showed positive ER $\beta$ promoter methylation for their future likelihood of developing PCa.

In summary, we found that overexpression of C/EBP $\beta$ promoted proliferation and inhibited apoptosis, and overexpression of $C / E B P \beta$ decreased the expression of ER $\beta$. We suppose that the methylation of the ER $\beta$ promoter may be an underlying genetic mechanism of PCa tumorigenesis and may contribute to the familial aggregation of the disease. C/ $\mathrm{EBP} \beta$ might be a potential therapeutic target for treating $\mathrm{PCa}$ though in vivo studies conducted in animal models are still needed.

Acknowledgements: This study was supported by the science and technology plan of Guangdong Province in 2011 (2011B031800092), the Guangdong Natural Science Foundation in 2011 (S2011010000641), the Guangdong Natural Science Foundation (2015A030313530) and the natural science foundation of China (201208310268).

\section{References}

[1] SIEGEL RL, MILLER KD, JEMAL A. Cancer statistics, 2016. CA Cancer J Clin 2016; 66: 7-30. doi: 10.3322/caac.21332

[2] MILNE AN, CARNEIRO F, O'MORAIN C, OFFERHAUS GJ. Nature meets nurture: molecular genetics of gastric cancer. Hum Genet 2009; 126: 615-628. doi: 10.1007/s00439009-0722-X

[3] BARRY KH, MOORE LE, LIAO LM, HUANG WY, ANDREOTTI $G$ et al. Prospective study of DNA methylation at LINE-1 and Alu in peripheral blood and the risk of prostate cancer. Prostate 2015; 75: 1718-1725. doi: $10.1002 /$ pros. 23053

[4] LI Y, PAN P, QIAO P, LIU R. Downregulation of N-myc downstream regulated gene 1 caused by the methylation of CpG islands of NDRG1 promoter promotes proliferation and invasion of prostate cancer cells. Int J Oncol 2015; 47: 1001-1008. doi: 10.3892/ijo.2015.3086

[5] MOSTAFAVI-POUR Z, KIANPOUR S, DEHGHANI M, MOKARRAM P, TORABINEJAD $S$ et al. Methylation of Integrin alpha4 and E-Cadherin Genes in Human Prostate Cancer. Pathol Oncol Res 2015; 21: 921-927. doi: 10.1007/ $\underline{\text { s12253-015-9917-8 }}$ 
[6] YU J, ZHANG H, GU J, LIN S, LI J et al. Methylation profiles of thirty four promoter-CpG islands and concordant methylation behaviours of sixteen genes that may contribute to carcinogenesis of astrocytoma. BMC Cancer 2004; 4: 65.

[7] RODRIGUES DN, BUTLER LM, ESTELLES DL, DE BONO JS. Molecular pathology and prostate cancer therapeutics: from biology to bedside. J Pathol 2014; 232: 178-184. doi: $\underline{10.1002 / \text { path. } 4272}$

[8] OSADA S, YAMAMOTO H, NISHIHARA T, IMAGAWA M. DNA binding specificity of the CCAAT/enhancer-binding protein transcription factor family. J Biol Chem 1996; 271: 3891-3896.

[9] SEBASTIAN T, MALIK R, THOMAS S, SAGE J, JOHNSON PF. C/EBPbeta cooperates with RB:E2F to implement Ras(V12)-induced cellular senescence. EMBO J 2005; 24: 3301-3312.

[10] KIM MH, FIELDS J. Translationally regulated C/EBP beta isoform expression upregulates metastatic genes in hormone-independent prostate cancer cells. Prostate 2008; 68: 1362-1371. doi: 10.1002/pros.20801

[11] ZHANG J, GONIT M, SALAZAR MD, SHATNAWI A, SHEMSHEDINI L et al. C/EBPalpha redirects androgen receptor signaling through a unique bimodal interaction. Oncogene 2010; 29: 723-738. doi: 10.1038/onc.2009.373

[12] JIA L, BERMAN BP, JARIWALA U, YAN X, COGAN JP et al. Genomic androgen receptor-occupied regions with different functions, defined by histone acetylation, coregulators and transcriptional capacity. PLoS One 2008; 3: e3645. doi: $\underline{\text { 10.1371/journal.pone.0003645 }}$

[13] KIM MH, MINTON AZ, AGRAWAL V. C/EBPbeta regulates metastatic gene expression and confers TNF-alpha resistance to prostate cancer cells. Prostate 2009; 69: 1435-1447. doi: $\underline{10.1002 / \text { pros. } 20993}$

[14] HELDRING N, PIKE A, ANDERSSON S, MATTHEWS J, CHENG G et al. Estrogen receptors: how do they signal and what are their targets. Physiol Rev 2007; 87: 905-931.

[15] BARRY DELONGCHAMPS N. Prostate cancer: review in 2014. Diagn Interv Imaging 2014; 95: 739-742. doi: $\underline{10.1016 / j . d i i i .2014 .06 .005}$
[16] ELLEM SJ, RISBRIDGER GP. Treating prostate cancer: a rationale for targeting local oestrogens. Nat Rev Cancer 2007; 7: 621-627.

[17] ADAMS JY, LEAV I, LAU KM, HO SM, PFLUEGER SM. Expression of estrogen receptor beta in the fetal, neonatal, and prepubertal human prostate. Prostate 2002; 52: 69-81.

[18] IMAMOV O, MORANI A, SHIM GJ, OMOTO Y, THULINANDERSSON C et al. Estrogen receptor beta regulates epithelial cellular differentiation in the mouse ventral prostate. Proc Natl Acad Sci U S A 2004; 101: 9375-9380.

[19] CHENG J, LEE EJ, MADISON LD, LAZENNEC G. Expression of estrogen receptor beta in prostate carcinoma cells inhibits invasion and proliferation and triggers apoptosis. FEBS Lett 2004; 566: 169-172.

[20] MCPHERSON SJ, ELLEM SJ, SIMPSON ER, PATCHEV V, FRITZEMEIER KH et al. Essential role for estrogen receptor beta in stromal-epithelial regulation of prostatic hyperplasia. Endocrinology 2007; 148: 566-574.

[21] WANG L, ZHANG P, MENG X, CHEN X, XIANG Z et al. Correlation between the germline methylation status in ERbeta promoter and the risk in prostate cancer: a prospective study. Fam Cancer 2016; 15: 309-315. doi: 10.1007/s10689015-9850-8

[22] DI CELLO F, COPE L, LI H, JESCHKE J, WANG W et al. Methylation of the claudin 1 promoter is associated with loss of expression in estrogen receptor positive breast cancer. PLoS One 2013; 8: e68630. doi: 10.1371/journal. pone. 0068630

[23] ZHU S, OH HS, SHIM M, STERNECK E, JOHNSON PF et al. C/EBPbeta modulates the early events of keratinocyte differentiation involving growth arrest and keratin 1 and keratin 10 expression. Mol Cell Biol 1999; 19: 7181-7190.

[24] SINGAL, R, GINDER, G. DNA methylation. Blood 1999; 9: 4059-4070.

[25] AGUILAR-MORANTE D, CORTES-CANTELI M, SANZSANCRISTOBAL M, SANTOS A, PEREZ-CASTILLO A. Decreased CCAAT/enhancer binding protein beta expression inhibits the growth of glioblastoma cells. Neuroscience 2011; 176: 110-119. doi: 10.1016/j.neuroscience.2010.12.025 